\title{
Investigating Textbook Reserves: A Case Study of Two Models for Reserves Collections
}

\section{Stephanie Pitts-Noggle and Ryan Rafferty}

\begin{abstract}
This article examines the behaviors and preferences of medical and nursing students in relation to their required textbooks and library reserves. The findings are based on an April 2015 survey at the University of Illinois-Chicago satellite Library of the Health Sciences in Urbana, where the library provides access to textbooks through traditional "closed" reserves in addition to an "open" reserves collection. Results indicate several barriers to usability regarding traditional reserves services and suggest that students prefer open reserves for convenience and savings. While broad applicability of the model warrants further investigation, academic libraries may be better able to meet patron needs by implementing open textbook reserves.
\end{abstract}

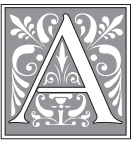

s textbook prices have steadily increased, academic libraries have considered what role they might play in mitigating this burdensome expense for students. Research has shown that the price of textbooks has increased 812 percent since 1978-a rate of increase greater than medical services and new home prices. ${ }^{1}$ In 2005, the U.S. Government Accountability Office (GAO) reported that new college textbook prices had increased at twice the rate of annual inflation since 1986; and more recent data have shown that this trend has continued, with the price of textbooks rising at roughly 6 percent per year from 2006 through $2012 .{ }^{2}$ While the Higher Education Opportunity Act, passed in 2008, made provisions for increasing transparency about the pricing of textbooks and course materials, stakeholders maintain it has had little effect on faculty decision-making when selecting textbooks. ${ }^{3}$ In a 2013 report on the bill, the GAO concluded that increased transparency has empowered students to find lower-cost options; however, this has had no effect on the overall price of textbooks. ${ }^{4}$

While the library's role in providing access to textbooks has been debated at length, the University of Illinois at Chicago's (UIC) Library of the Health Sciences-Urbana (LHSU) has been collecting numerous copies of required and recommended medical and nursing textbooks since the library opened. Initially, the textbooks were located in a closed reserves collection found behind the circulation desk, made available to students with the assistance of circulation staff for 3-hour, in-library use. However, in 2002, LHSU also began providing access to additional copies of required and rec-

Stephanie Pitts-Noggle is a graduate student at the School of Information Sciences, University of Illinois Urbana-Champaign; e-mail: pittsno2@illinois.edu. Ryan Rafferty is an Assistant Professor and Regional Head Librarian for the Library of the Health Sciences-Urbana at the University of Illinois-Chicago; e-mail: rraffer2@uic.edu. (C2017 Stephanie Pitts-Noggle and Ryan Rafferty, Attribution-NonCommercial (http:// creativecommons.org/licenses/by-nc/3.0/) CC BY-NC. 
ommended textbooks without the aid of a staff member through the open reserves collection.

Textbooks from this collection, which is primarily oriented toward medical students, can be used by students in the library or checked out for a 24-hour period. Open reserves materials are cataloged and have a barcode so they are searchable in the OPAC and can be checked out using the library's circulation software (Voyager by Ex Libris). Materials can be renewed up to three times. Renewals can be processed in-person, over the phone, or via the OPAC. Patrons receive fines for late or lost items. Open reserves materials are reshelved as soon as possible upon being discharged. While anyone can use materials from the open reserves collection in the library, only College of Medicine or College of Nursing students, faculty, and staff are allowed to check out items from that collection.

LHSU is a regional library that predominantly serves the students, staff, and faculty of the UIC satellite campuses of the Colleges of Medicine and Nursing in Urbana, Illinois. The library focuses on providing a robust collection and opportunities to enhance the learning experiences of this specialized audience. Anecdotal evidence gathered while staffing the reference desk and in taking hourly head counts suggested that first-year medical students (M1) use the physical space of the library more than any other group; this comes as no surprise, as the M1 population makes up a full quarter of the on-campus medical student population. As a result, the reserves collections were developed to buttress their learning needs. The M1 curriculum establishes foundational knowledge in several medical subject areas such as anatomy, physiology, embryology, biochemistry, neurology, and immunology.

Throughout the 2014-2015 school year, casual observation and circulation statistics indicated that the open reserves collection was quite popular, while the circulation of closed reserves appeared to be languishing by comparison. However, the library had not formally evaluated student usage and satisfaction or their ideas for how these collections might be improved; further information was needed to understand patron preferences regarding the purchase and use of textbooks. For LHSU to make informed decisions about collection policies and practices, and further its user-oriented library mission, such an undertaking was necessary.

A survey was developed and distributed in the spring of 2015 that assessed students' perceived use and satisfaction with both the closed and open reserves collections. The purpose of the survey was to identify whether the reserves collections met the needs of medical and nursing students throughout the different stages of their education and what improvements could be made. The researchers also sought to uncover student attitudes and preferences regarding required textbooks and determine what value they saw in the library's reserve textbook services.

\section{Literature Review}

Very little had been written about collecting textbooks in academic libraries before 2005, when the GAO published their findings on rising textbook prices. A 1990 paper by Sommer and Estabrook found that faculty members at four-year institutions significantly underestimated the cost of textbooks; this had considerable implications for library budgets. ${ }^{5}$ Further, in 1994, Sayles examined the collection development policies of twenty-seven college libraries and noted that the policies were often contradictory with regard to textbooks, stressing the importance of collecting based on student need while dismissing textbooks as inappropriate for the collection. ${ }^{6}$

In 2005, Hsieh and Runner conducted a survey and collection development policy analysis that probed into libraries' practices and policies surrounding the acquisition of textbooks and leisure reading materials. ${ }^{7}$ Sixty-one percent of respondents reported 
that their library had specific "no textbooks" policies, citing budgetary concerns as the primary reason for avoiding the practice and, second, that purchasing textbooks was the students' responsibility. ${ }^{8}$

Pilot projects initiated after 2005 in response to these articles and the GAO report have focused on developing textbook reserve collections and services. The University of Minnesota undertook such a project in the spring of $2005 .{ }^{9}$ The textbooks received greater use than most titles in the library collection; however, they circulated at a lower rate than expected. In 2005, the University of Illinois at Urbana-Champaign began a pilot project aimed at undergraduate students. ${ }^{10}$ Though faculty and students responded favorably to the service and the books circulated at a higher rate than the reserve collection average, the cost to the library was prohibitive and the project was not continued. McElfresh concluded in 2009 that the bump in reserve statistics at the Oklahoma State University at Oklahoma City library was a result of students availing themselves to the textbooks put on reserve at faculty request; as a result, the library would add textbooks to the reserve collection on a permanent basis. ${ }^{11}$

Several studies were specifically initiated in response to student demand for the library to provide access to textbooks. In 2007, Murphy described the University of Oklahoma library that, after years of pressure from Student Congress, implemented a "Textbooks on Reserve" program. ${ }^{12}$ Based on circulation statistics, Murphy concluded that the project was a success, though, given continued skyrocketing textbook costs, questions about its future remained. From 2006 through 2009, Pollitz et al. published a series of reports probing the viability of a textbook program for the library in response to an item in Oregon State University's student newspaper calling for the library to put required textbooks on reserve. ${ }^{13}$ Significantly, they found that 49 percent of students reported spending $\$ 750$ or more each year on textbooks. ${ }^{14}$ The second study of Pollitz et al. from 2009 surveyed eighty-four libraries about their practices regarding reserves and textbooks; the majority (67\%) did not buy textbooks at all, even for reserves. ${ }^{15}$

In recent years, scholarly focus had shifted away from physical reserves and toward alternatives such as custom publishing models and electronic reserves. Several university libraries have pushed for "open educational resources" (OER) through participation in "open textbook" programs that engage content writers in creating high-quality educational materials that are free to access on the Internet and/or at low cost to purchase as a physical text. ${ }^{16}$ The SUNY Open Textbooks program is an example of the former, with the libraries acting in the role of publisher. ${ }^{17}$ Rice University's OpenStax College textbook program has made similar materials more widely available through the OER model; in February 2015, thirteen California State University libraries began pushing for increased usage of the OpenStax resources. ${ }^{18}$ Other examples of OERs include materials published by startup Boundless.com, as well as multiuniversity e-content pilot initiative NET+, adopted by the University of Buffalo in fall 2012. ${ }^{19}$

While e-books have been a great boon to students and library reserves services alike, several studies suggest that, with regard to textbooks, they fail to meet student needs. At the California Institute of Integral Studies, a 2006 survey showed that, if the cost were equal, students preferred easily accessible print materials to online reserves. ${ }^{20}$ Christie et al. found that 93 percent of respondents preferred print textbooks over electronic editions. ${ }^{21}$ Further, in response to a 2010 study, Rojeski noted that, while electronic copies were preferred for their accessibility, most students (78\%) disliked reading online.22 In 2012, a study developed by the University of Wisconsin, Cornell University, the University of Minnesota, the University of Virginia, and Indiana University found that students preferred print to digital when it came to studying, as digital formats were cumbersome and lacked the desired usability. ${ }^{23}$ A 2014 study by Lyons and Hendrix found that students are still divided on their preference for e-textbooks, 
despite finding them easy to use. ${ }^{24}$ Regarding graduate-level professional programs, Strother et al. surveyed dental school students in 2009 regarding their experiences using digital textbooks; an overwhelming majority of students reported disliking reading large portions of text online, but 68 percent said they found the search function feature very useful..$^{25}$

Textbooks in particular are preferred in physical formats for engaging closely with the text. ${ }^{26}$ However, students find the cost of textbooks burdensome, and many students look to the library as a way to alleviate that burden. If libraries are to meet user needs, the long-held belief that textbooks are not appropriate for academic library collections ought to be jettisoned and textbook policies reconsidered. Access is another consideration; libraries need to consider student preference when developing the services through which textbooks will be made available.

\section{Research Questions}

During the 2014-2015 academic year, staff at LHSU perceived a discrepancy between the popularity of the open reserves materials and the closed reserves. The circulation statistics bore out this observation: between July of 2014 and June of 2015, closed reserves materials ( $n=194$, composed of 141 medicine and 53 nursing texts) circulated 659 times, while open reserves materials $(n=165$, solely medicine texts) circulated 900 times. However, these data do not reflect the total use of open reserves, as these materials can be taken off the shelf by patrons and used in the library without a checkout. The survey sought to gain a more complete understanding of how often open reserves materials were actually being used and how the closed reserves fared by comparison. Faced with the task of optimizing LHSU's collections generally, library staff determined that students' attitudes toward both reserves collections would significantly aid in identifying areas for improvement. Thus, the survey queried students' perceived use of textbooks from the closed and open reserves collections and sought to determine their overall satisfaction with them.

In conducting a literature review, we became aware of the limited success of several libraries' textbook reserves programs, given low circulation statistics and prohibitive costs, as well as students' preference for studying from print textbooks over digital. We hypothesized that the open reserves model might provide a possible solution to some of the low circulation statistics observed in other pilot projects and offer an alternative to digital texts that do not satisfy student needs, especially for libraries catering to graduate students in professional schools. ${ }^{27}$

\section{Methods}

In April 2015, LHSU distributed a web-based survey via e-mail to all medical and nursing students (approximately 450 students) enrolled at the UIC Urbana campus. Survey responses were collected using the university-hosted version of Qualtrics survey software. The survey was open for two weeks. A reminder e-mail was sent a week after the survey was launched. Respondents were not offered an incentive to take the survey. Students who had never used either of the reserves collections were asked 6 questions, while students who used at least one collection were asked a total of 21 questions. Only completed surveys were considered for analysis; a survey was considered complete if and only if answers were supplied to the predefined set of five mandatory questions. Three of the 39 surveys collected were incomplete.

\section{Results}

We received 36 completed surveys, for a response rate of approximately 8 percent. The response rate among the medical students was considerably higher than the nursing 
students; of approximately 250 medical students, we received 31 responses, a response rate of approximately 12 percent. However, out of approximately 200 nursing students, we received just 5 responses, a response rate of about 2 percent. Of the medical student respondents, there were eight M1 students, ten M2s, three M3s, four M4s, and six MD PhD students. Two undergraduates and three graduate students from the College of Nursing completed the survey. Due to the low response rate and small sample size for each category, it is not possible to conduct statistical analysis on our data with reliable results. Therefore, this paper provides comparative analyses of the various user groups and categories of responses to illustrate collections use patterns.

\begin{tabular}{|c|c|c|c|c|c|c|c|c|}
\hline \multicolumn{9}{|c|}{$\begin{array}{l}\text { TABLE } 1 \\
\text { Results from questions about the closed reserves collection. }\end{array}$} \\
\hline Question/Response & M1 & M2 & M3 & M4 & $\begin{array}{l}\mathrm{MD} / \\
\mathrm{PhD}\end{array}$ & $\begin{array}{c}\text { UG } \\
\text { Nursing }\end{array}$ & $\begin{array}{c}\text { Grad } \\
\text { Nursing }\end{array}$ & Total \\
\hline \multicolumn{9}{|c|}{ How often do you use items from the reserves collection? } \\
\hline More than twice a week & 0 & 0 & 0 & 0 & 0 & 1 & 0 & 1 \\
\hline Once or twice a week & 0 & 2 & 0 & 0 & 0 & 0 & 0 & 2 \\
\hline Once or twice a month & 2 & 1 & 0 & 1 & 0 & 0 & 0 & 4 \\
\hline Once or twice a semester & 3 & 5 & 0 & 2 & 1 & 0 & 1 & 12 \\
\hline Never & 3 & 1 & 1 & 1 & 1 & 0 & 1 & 8 \\
\hline Number of Respondents & 8 & 9 & 1 & 4 & 2 & 1 & 2 & 27 \\
\hline \multicolumn{9}{|c|}{$\begin{array}{l}\text { Which of the following statements about the reserves collection apply to you? (check all } \\
\text { that apply) }\end{array}$} \\
\hline I don't know about them & 1 & 3 & 0 & 0 & 0 & 0 & 0 & 4 \\
\hline I don't know what is offered & 3 & 5 & 0 & 1 & 1 & 0 & 0 & 10 \\
\hline $\begin{array}{l}\text { I don't like having to ask } \\
\text { someone for a book }\end{array}$ & 1 & 1 & 0 & 1 & 0 & 0 & 0 & 3 \\
\hline The checkout period is too short & 0 & 1 & 0 & 2 & 1 & 1 & 1 & 6 \\
\hline $\begin{array}{l}\text { The books I want are often } \\
\text { unavailable }\end{array}$ & 0 & 1 & 0 & 1 & 0 & 0 & 1 & 3 \\
\hline $\begin{array}{l}\text { None of the above; I am satisfied } \\
\text { with the reserve collection }\end{array}$ & 4 & 2 & 1 & 2 & 0 & 0 & 1 & 10 \\
\hline Number of Respondents & 7 & 9 & 1 & 4 & 2 & 1 & 2 & 26 \\
\hline \multicolumn{9}{|c|}{ How could the reserves collection be improved? (check all that apply) } \\
\hline $\begin{array}{l}\text { Increase the length of the } \\
\text { checkout period }\end{array}$ & 1 & 1 & 0 & 3 & 1 & 2 & 1 & 9 \\
\hline $\begin{array}{l}\text { Make them available without } \\
\text { help from circulation staff (like } \\
\text { open reserves) }\end{array}$ & 2 & 2 & 0 & 1 & 2 & 1 & 0 & 8 \\
\hline Put different titles on reserve & 0 & 0 & 0 & 0 & 1 & 0 & 0 & 1 \\
\hline $\begin{array}{l}\text { Make it clearer what is offered } \\
\text { on reserve }\end{array}$ & 4 & 10 & 2 & 1 & 4 & 0 & 1 & 22 \\
\hline Other-Text response & 0 & 0 & 0 & 0 & 1 & 0 & 1 & 2 \\
\hline Number of Respondents & 5 & 10 & 2 & 4 & 5 & 2 & 3 & 31 \\
\hline
\end{tabular}


Seventy-five percent $(n=27)$ of the total responding students reported using at least one of the reserves collections. All of the M1 respondents reported using the reserves collections, while 70 percent (16 out of 23) of the M2-M4 and MD PhD students had used them. Sixty percent of the nursing students $(n=3)$ had used at least one of the reserves collections. When asked why students used the collections, most students $(81 \%, n=22)$ said that they had saved money by using the library's copy instead of purchasing their own, and a majority $(63 \%, n=17)$ agreed they found it convenient. Further, 14 (52\%) used them because the textbooks were recommended by or required for their courses. For the nine students who reported having never used either of the reserves collection, the most common reason $(56 \%, n=5)$ was that they did not know about them. Interestingly, two of these respondents (22\%) reported that the reason they did not use the reserves was that they did not like going to the library.

Table 1 shows the responses to questions about behaviors and attitudes regarding the closed reserves collection. Only those students who reported using one of the reserves collections $(n=27)$ were asked about their usage of these collections. When asked about the frequency with which they used closed reserves, 74 percent of students $(n=20)$ reported using this collection infrequently; of these 20 students, 12 (44\%) stated that they used the collection less than twice a semester, and 8 (30\%) never used closed reserves at all. Attitudes toward the collection spoke to the somewhat low usage statistics: more than half of the respondents $(54 \%, \mathrm{n}=14)$ reported either not knowing what was offered on reserve or that they did not know about the collection at all. Several students $(23 \%, n=6)$ believed that the checkout period was too short. Conversely, 10 students $(38 \%)$ reported feeling satisfied with the closed reserves collection.

In terms of improving the collection, the majority of respondents $(71 \%, \mathrm{n}=22)$ agreed with the statement that the library should make it clearer what materials are offered in the closed reserves collection. A smaller group of respondents believed that the collection could be improved by increasing the length of checkout period $(29 \%, n=$ 9 ), and some agreed that this could be achieved by making materials available without the help of circulation staff $(26 \%, \mathrm{n}=8)$.

Student behaviors and attitudes toward open reserves are represented in table 2. Usage of the open reserves was varied, but the majority of students $(67 \%, n=18)$ used them once a month or more. Only 7 percent $(n=2)$ reported never using the open reserves. Regarding where students used open reserves materials, 44 percent $(n=12)$ used them in the library without checking them out, whereas 26 percent $(n=7)$ most often checked textbooks out. Another 26 percent indicated they used reserves textbooks both in the library and by checking them out, equally.

Of the students who identified as having used one of the reserves collections, all but one respondent $(96 \%, \mathrm{n}=26)$ reported being either satisfied or very satisfied with open reserves. This trend was further disclosed by what students said they liked about the open reserves collection: the majority liked that they could use textbooks without having to check them out $(81 \%, \mathrm{n}=21)$, that they had saved money using the library's copy instead of purchasing their own $(77 \%, \mathrm{n}=20)$, and that they used the collection because they found it convenient $(77 \%, n=20)$. Further, $12(46 \%)$ liked that, when they forgot their textbook, the library's copy served as a backup.

When asked what they did not like about open reserves, half of the respondents (n $=9$ ) said there were too few copies and that the checkout period was too short. Seven students (39\%) felt the textbooks they needed were often unavailable. These opinions mirrored what students identified as areas for improvement: most believed open reserves could be improved by adding more copies $(61 \%, n=19)$, increasing the length of the checkout period $(48 \%, \mathrm{n}=15)$, and adding new titles that are not currently on reserve $(32 \%, \mathrm{n}=10)$. 


\begin{tabular}{|c|c|c|c|c|c|c|c|c|}
\hline \multicolumn{9}{|c|}{$\begin{array}{l}\text { TABLE } 2 \\
\text { Results from Questions about the Open Reserves Collection }\end{array}$} \\
\hline Question/Response & M1 & M2 & M3 & M4 & $\begin{array}{l}\mathrm{MD} / \\
\mathrm{PhD}\end{array}$ & $\begin{array}{c}\text { UG } \\
\text { Nursing }\end{array}$ & $\begin{array}{c}\text { Grad } \\
\text { Nursing }\end{array}$ & Total \\
\hline \multicolumn{9}{|c|}{ How often do you use items from the open reserves collection? } \\
\hline More than twice a week & 3 & 1 & 0 & 0 & 0 & 1 & 0 & 5 \\
\hline Once or twice a week & 3 & 1 & 0 & 0 & 0 & 0 & 0 & 4 \\
\hline Once or twice a month & 1 & 4 & 0 & 1 & 2 & 0 & 1 & 9 \\
\hline Once or twice a semester & 1 & 3 & 1 & 2 & 0 & 0 & 0 & 7 \\
\hline Never & 0 & 0 & 0 & 1 & 0 & 0 & 1 & 2 \\
\hline Number of Respondents & 8 & 9 & 1 & 4 & 2 & 1 & 2 & 27 \\
\hline \multicolumn{9}{|c|}{ When I use items from open reserves, I most often... } \\
\hline Check them out & 2 & 0 & 1 & 3 & 0 & 0 & 1 & 7 \\
\hline $\begin{array}{l}\text { Use them in the library without } \\
\text { checking them out }\end{array}$ & 5 & 6 & 0 & 1 & 0 & 0 & 0 & 12 \\
\hline Check them out or not equally & 1 & 3 & 0 & 0 & 2 & 1 & 0 & 7 \\
\hline I don't use the open reserves & 0 & 0 & 0 & 0 & 0 & 0 & 1 & 1 \\
\hline Number of Respondents & 8 & 9 & 1 & 4 & 2 & 1 & 2 & 27 \\
\hline \multicolumn{9}{|c|}{ How could the open reserves collection be improved? (check all that apply) } \\
\hline Add more copies of titles on open reserve & 5 & 6 & 0 & 2 & 4 & 2 & 0 & 19 \\
\hline Increase the length of the checkout period & 1 & 5 & 1 & 3 & 2 & 1 & 2 & 15 \\
\hline $\begin{array}{l}\text { Add new titles that are not currently on } \\
\text { open reserves }\end{array}$ & 3 & 1 & 1 & 2 & 2 & 0 & 1 & 10 \\
\hline Make it easier to find what I want & 0 & 1 & 1 & 0 & 2 & 0 & 0 & 4 \\
\hline Other-Text response & 1 & 0 & 0 & 0 & 0 & 0 & 1 & 2 \\
\hline Number of Respondents & 6 & 9 & 2 & 4 & 5 & 2 & 3 & 31 \\
\hline \multicolumn{9}{|c|}{ Rate your overall satisfaction with the open reserves collection. } \\
\hline Very satisfied & 4 & 5 & 0 & 3 & 1 & 1 & 0 & 14 \\
\hline Satisfied & 4 & 4 & 1 & 1 & 1 & 0 & 1 & 12 \\
\hline Neither satisfied nor dissatisfied & 0 & 0 & 0 & 0 & 0 & 0 & 1 & 1 \\
\hline Dissatisfied & 0 & 0 & 0 & 0 & 0 & 0 & 0 & 0 \\
\hline Very dissatisfied & 0 & 0 & 0 & 0 & 0 & 0 & 0 & 0 \\
\hline Not sure/not applicable & 0 & 0 & 0 & 0 & 0 & 0 & 0 & 0 \\
\hline Number of Respondents & 8 & 9 & 1 & 4 & 2 & 1 & 2 & 27 \\
\hline \multicolumn{9}{|c|}{ Things I like about open reserves (check all that apply) } \\
\hline $\begin{array}{l}\text { I can use them without having to check } \\
\text { them out }\end{array}$ & 7 & 9 & 1 & 2 & 1 & 0 & 1 & 21 \\
\hline It is convenient & 7 & 8 & 0 & 3 & 1 & 1 & 0 & 20 \\
\hline $\begin{array}{l}\text { I have saved money by using the } \\
\text { library's copy instead of buying my own }\end{array}$ & 7 & 6 & 1 & 2 & 2 & 1 & 1 & 20 \\
\hline $\begin{array}{l}\text { When I forget to bring my book, the } \\
\text { library's copy serves as a backup }\end{array}$ & 4 & 5 & 0 & 1 & 2 & 0 & 0 & 12 \\
\hline Number of Respondents & 8 & 9 & 1 & 3 & 2 & 1 & 2 & 26 \\
\hline
\end{tabular}


All 36 respondents were asked about their preferences and purchasing behaviors with regard to required textbooks (see table 3$)$. Sixty-nine percent of students $(n=25)$ reported owning only some or none of their required textbooks. Just 11 percent $(n=4)$ reported owning all of their required textbooks. Nearly half of the students $(43 \%, n=15)$ indicated that they most often used their own copies of required textbooks; however, using the library's copy was a close second, with 31 percent $(n=11)$ reporting that this was their usual approach. Regarding textbook use preferences, the greatest number prefer to use a personal copy $(40 \%, n=14), 23$ percent of students $(n=8)$ prefer using the library's copy, and 26 percent $(n=9)$ would prefer to use an e-book.

\section{Discussion}

As academic libraries move toward creating more user-driven spaces and services, it comes as something of a surprise that there is such a dearth of current literature on providing textbooks for student use; with numerous pilot projects citing student demand as the motive for their inception, it is clear that students are looking to the

\begin{tabular}{|c|c|c|c|c|c|c|c|c|}
\hline \multicolumn{9}{|c|}{$\begin{array}{l}\text { TABLE } 3 \\
\text { Results from Questions about the Students' Textbooks }\end{array}$} \\
\hline Question / Response & M1 & M2 & M3 & M4 & $\begin{array}{l}\mathrm{MD} / \\
\mathrm{PhD}\end{array}$ & $\begin{array}{c}\text { UG } \\
\text { Nursing }\end{array}$ & $\begin{array}{c}\text { Grad } \\
\text { Nursing }\end{array}$ & Total \\
\hline \multicolumn{9}{|c|}{ How many of the textbooks required for your courses do you own? } \\
\hline None & 2 & 2 & 1 & 1 & 2 & 0 & 0 & 8 \\
\hline Some & 5 & 5 & 2 & 1 & 3 & 0 & 1 & 17 \\
\hline Most & 1 & 2 & 0 & 1 & 1 & 1 & 1 & 7 \\
\hline All & 0 & 1 & 0 & 1 & 0 & 1 & 1 & 4 \\
\hline Number of Respondents & 8 & 10 & 3 & 4 & 6 & 2 & 3 & 36 \\
\hline \multicolumn{9}{|c|}{ With regard to your textbooks, you most often... } \\
\hline Use my own copy & 1 & 3 & 0 & 3 & 4 & 2 & 2 & 15 \\
\hline Use the library's copy & 5 & 4 & 0 & 0 & 1 & 0 & 1 & 11 \\
\hline Share a copy with a friend & 1 & 1 & 0 & 0 & 1 & 0 & 0 & 3 \\
\hline I don't use my required textbooks & 1 & 2 & 1 & 1 & 0 & 0 & 0 & 5 \\
\hline $\begin{array}{l}\text { The College of Medicine supplies } \\
\text { my textbooks }\end{array}$ & 0 & 0 & 1 & 0 & 0 & 0 & 0 & 1 \\
\hline Number of Respondents & 8 & 10 & 2 & 4 & 6 & 2 & 3 & 35 \\
\hline \multicolumn{9}{|c|}{ With regard to your required textbooks, your preference would be... } \\
\hline Use my own copy & 3 & 4 & 0 & 3 & 2 & 1 & 1 & 14 \\
\hline Use the library's copy & 4 & 1 & 0 & 0 & 1 & 1 & 1 & 8 \\
\hline Use an online edition (e-book) & 1 & 4 & 1 & 0 & 3 & 0 & 0 & 9 \\
\hline Share with a friend & 0 & 0 & 0 & 0 & 0 & 0 & 0 & 0 \\
\hline Borrow from someone else & 0 & 0 & 0 & 0 & 0 & 0 & 1 & 1 \\
\hline $\begin{array}{l}\text { The College of Medicine supplies } \\
\text { my textbook }\end{array}$ & 0 & 1 & 1 & 1 & 0 & 0 & 0 & 3 \\
\hline Other-Text response & 0 & 0 & 0 & 0 & 0 & 0 & 0 & 0 \\
\hline Number of Respondents & 8 & 10 & 2 & 4 & 6 & 2 & 3 & 35 \\
\hline
\end{tabular}


library to alleviate some of the cost burden associated with buying required textbooks. While faculty can play a role in solving this problem - libraries also benefit from faculty selection of less expensive textbooks or open educational resources - the library has a lot to offer this endeavor as well.

Here it must be acknowledged that the survey's low response rate affects the broad applicability of these findings. Despite this, it is significant that the results mapped onto the hypotheses that were developed based on observation and circulation data. While the data gained from the nursing students cannot wisely be used to draw significant conclusions, we are confident that the responses reflect the behaviors and attitudes of UIC-Urbana's medical students.

The survey results were vital to understanding if the open reserves collection was reaching the M1s, the group for which it was created. The second- through fourth-year medical students and those in the MD PhD program are in the building less frequently, as one of the students noted in a free text box: "It is inconvenient to go to the library since M2-M4 involves little time on campus." The nursing students are also a special group, because their required textbooks were only available through closed reserves. We believed they would have a different perspective on the reserves collections from that of the medical students.

It is significant that all of the M1s who completed the survey indicated that they used the closed reserves and/or the open reserves. It was surprising that nine out of the ten responding M2s and all M4s reported using one or both of the collections, despite decreased time on campus. A greater number of M3s and MD PhDs reported not having used either of the collections, which aligned with our assumptions. Of the 5 nursing students who responded, 3 reported that they used the open reserves; unexpectedly, there were only 3 who used closed reserves. Given the location of their textbooks, the assumption was that nearly all of this group would report using the closed reserves. The response rate among the nursing students was too small to accurately assess if this was a trend; nonetheless, it is interesting that an equal number reported having used each of the reserves collections. When asked what they liked about open reserves, two nursing students agreed that they had saved money by using the collection, one stated that it was convenient, and one liked that textbooks could be used without being checked out. Evidently, the textbooks in the open reserves meet the needs of a broader patron base beyond the medical students for whom it was specifically tailored.

Students' perceived frequency of use of the collections corroborated our observations: the open reserves were used more than the closed reserves. Students' reported use of open reserves materials within the library without checking them out confirmed our hypothesis that the circulation statistics were not telling the whole story; since 44 percent of students most often used items in the library, and an additional 26 percent used them in the library and checked them out equally, a conservative estimate of actual use for the open reserves collection is between two to three times higher than the circulation statistics indicate.

Only a third of respondents ( 9 out of 27) reported using open reserves less than once a month, a statistic that bespeaks a popular collection. Of the M1 students, however, 6 out of 8 used them once a week or more. As the collection is aimed at this group in particular, it speaks volumes that they were availing themselves of the collection with such frequency. It would seem that for this population open reserves are not simply popular: they are essential.

The reasons that respondents used the reserves collections were somewhat surprising. We had anticipated that some students would believe they had saved money using reserves, based on student expectations and attitudes cited by authors in the literature review, ${ }^{28}$ but 81 percent was a startlingly high number (22 of 27 respondents agreed 
with this statement). We did not expect it to be the most agreed-with statement, even above "convenience," which was selected by 17 respondents (63\%). Additionally, four students filled in the free text option, one of whom said, "Some non-required but uniquely informative texts I've found available, and so will occasionally consult when I am in the library"; two others also wrote in this free text space that they used the open reserves as a supplemental resource. While students appreciate the convenience and savings of having their required texts available on reserve, it is meaningful that they also found value in having recommended and supplemental texts included in the collection as well.

When asked about the open reserves collection specifically, however, the most agreed-with statement $(81 \%, 21$ out of 26 respondents) was that students liked being able to use the materials without a checkout. This was followed closely by an equal number (77\%, 20 students) who agreed that the collection was convenient and that using the open reserves had saved them money. Given that the most popular response singled out the defining feature of the open reserves model-its accessibility-demonstrates how much students acknowledge and appreciate this innovation on the traditional reserves model.

Although the majority of students wanted to use personal copies of textbooks, that so many were happy using the library's copy is unsurprising considering the prevailing opinions that doing so was convenient and saved money. While the survey did not ask why students did or did not purchase their own copies of required textbooks, the disparity between the number of students who owned all their textbooks (11\%) and those who preferred using a personal copy $(40 \%)$ seems to confirm the portrait of students as discerning textbook consumers painted by the articles in the literature review. The prohibitive cost of textbooks has turned them into savvier and more selective consumers who turn to the library for help in lightening the burdensome expense. This trend was visible across a number of responses in the survey. The more startling revelation was the number of students (26\%) who stated their preference was to use an e-book. Our results support the findings from previous studies, such as Christie et al. and Rojeski, which showed students still prefer print to e-books. ${ }^{29}$ However, considering that our results indicated a slightly higher rate of preference for e-books than did those from earlier studies suggests that opinions may be shifting. It is worth noting that most of this group (8 out of 9) were advanced medical school students who, as in Strother's study, may appreciate the search functionality of e-books for quick clinical reference, while M1 students, in having to log many hours of study directly from textbooks, may dislike reading large portions of text online and thus prefer physical copies. ${ }^{30}$

The students' criticisms of the open reserves collection reflected what improvements they wanted to see: students wanted longer checkout times, more copies, and more titles. No one agreed with the statement "It is hard to find what I need"; however, when asked what could be improved, 4 people wanted to make it easier to find what they want. Since no one found it difficult to locate books in the collection, it seems likely that these respondents would be satisfied by the addition of a greater number of copies and titles to the collection. No one selected "The copies are in poor condition," either. While certain materials - fragile, rare, and/or expensive items - need the protection of the closed reserves model, textbooks benefit students most when they are accessible and available. Factors like convenience and saving money are valued above the textbooks' superficial appearance.

It came as a surprise that, out of 26 responses, 14 students either did not know what was offered on closed reserve or did not know about the collection at all. Clearly, the closed reserves collection would benefit from greater advertising. While some of the burden rests with faculty to inform students that their readings are available via 
reserve, it is ultimately the library's responsibility to make this information accessible and plentiful. Yet, in a library with limited staffing resources, the open reserves model may be the wiser option; with the titles out from behind the desk, the collection does some of the work of advertising itself. Additionally, LHSU's open reserves collection is distinguished by large signs affixed to the bookcases where the materials are located, while the closed reserves collection is not marked. These signs also make clear the length of the checkout period for open reserves ( 24 hours); by comparison, closed reserves are limited to a 3-hour checkout, which may not be clear to students using the collection for the first time. Furthermore, given that some patrons do not like to ask staff for help-12 percent according to this survey-the open reserves collection policies are altogether a more accessible, patron-centered model.

As many libraries' reserves policies impose similar limitations on where materials can be used, length of checkout period, and accessibility, it is understandable that 10 students were satisfied with LHSU's closed reserves collection. In considering other results from this study, however, we believe that these policies are in need of reexamination. The restrictiveness of traditional reserves policies may be responsible for the limited success of certain textbook pilot projects; at least two projects in the literature review reported low circulation statistics for textbooks on closed reserve. ${ }^{31}$ Inadequate ability to peruse the collection, hesitancy in asking staff for assistance, restrictions on where one can use reserves, and short checkout periods are all possible contributing factors to low reserves circulation statistics. Simply put, the inherent characteristics of each model necessarily result in an uneven playing field where open reserves naturally receive more use than closed reserves: In 2015, LHSU's open reserves circulated 1.4 times more than did the closed reserves despite having 15 percent fewer books. Even without taking into consideration the results of this survey-which found a marked preference among students for using open reserves without a checkout-these results are significant. While such data may not be a metric of success at every library, it is a quantifiable embodiment of LHSU's patron-centric mission.

The most telling result from the survey was the rate of satisfaction with open reserves: 44 percent reported being satisfied, while 52 percent were very satisfied. Reported satisfaction was fairly evenly distributed among the different levels of medical and nursing students. By comparison, only ten students reported feeling satisfied with the closed reserves. The difference in usage between the two collections asserts that open reserves is a successful model; however, the difference in the rate of satisfaction confirms that it is also the model that better suits our patrons' needs.

\section{Conclusions and Further Study}

Given the low rate of response in this study, further investigation should be done to see if such a program could benefit medical students in general, particularly larger medical schools. While the circulation numbers in conjunction with the survey results inspire confidence in the LHSU's open reserves program, a larger number of medical and nursing students should be surveyed to see if these preferences are consistent across this population. It is particularly promising that the M1 respondents are avid and enthusiastic users of the collection.

Could the open reserves model work for other professional graduate programs? It is possible that other programs with graduate students who use textbooks frequently as part of their studies could benefit from the open reserves model. Dentistry, veterinary, and law school students may be fruitful populations for open reserves pilot projects. An open reserves initiative for undergraduates may prove significantly more problematic given the cost and higher levels of library anxiety endemic to that population. Libraries that serve undergraduate students in STEM fields, however, may find success in 
implementing open reserves, as these textbooks are some of the most expensive and the heaviest, making them the least convenient to buy and carry to campus. ${ }^{32}$ Further study should be conducted by libraries considering the implementation of open reserves to assess the behaviors and preferences of their patrons, as there may be other potential challenges to the open reserves model that LHSU has not experienced. Textbook collections may present a higher risk for problems such as theft, vandalism, rapid deterioration, and burdensome, unforeseen costs. These unfortunate realities are to be expected occasionally in any library collection; libraries should carefully weigh these negatives against the potential for an open reserves textbook collection to strengthen the relationship between library and patron.

While the sample size was small, it confirmed our hypothesis about the reserves collections: students both use open reserves more and prefer it to closed reserves. They also want to see more titles and more copies on reserve. In response to these findings, LHSU has ceased offering books on closed reserve; all reserve textbooks are now available as part of the open reserves collection. This has increased the size of the collection in the number of copies as well as the variety of titles. The scope has also expanded; nursing textbooks now have their own section in the collection. A follow-up survey is planned to assess students' impressions of this new system to identify and address new challenges and opportunities for improvement. By making these changes, LHSU is furthering its mission of creating user-oriented spaces and services that optimize the library experience for its patrons.

\section{Notes}

1. Mark J. Perry, "The College Textbook Bubble and How the 'Open Educational Resources' Movement is Going Up Against the Textbook Cartel," American Enterprise Institute (Dec. 4, 2012), available online at https://www.aei.org/publication/the-college-textbook-bubble-and-how-theopen-educational-resources-movement-is-going-up-against-the-textbook-cartel/ [accessed 26 June 2015].

2. U.S. Government Accountability Office, Students Have Greater Access to Textbook Information, GAO-13-368 (Washington, D.C.: U.S. Government Printing Office, 2013).

3. Pub. L. No. 110-315, § 112(a), 122 Stat. 3078, 3107 (2008), codified at 20 U.S.C. § 1015b; U.S. Government Accountability Office, College Textbooks Enhanced Offerings Appear to Drive Recent Price Increases, GAO-05-806 (Washington, D.C.: U.S. Government Printing Office, 2005).

4. GAO, Students Have Greater Access to Textbook Information, 22.

5. Robert Sommer and Marina Estabrook, "Textbook Prices and Their Implications for Social Sciences Librarians," Behavioral E Social Sciences Librarian 9, no. 1 (1990): 29-37.

6. Jeremy Sayles, "The Textbooks-in-College-Libraries Mystery," College \& Undergraduate Libraries 1, no. 1 (1994): 81-93.

7. Cynthia Hsieh and Rhonelle Runner, "Textbooks, Leisure Reading, and the Academic Library," Library Collections, Acquisitions, and Technical Services 29, no. 2 (2005): 192-204.

8. Hsieh and Runner, "Textbooks," 196.

9. Caroline Crouse, "Textbooks 101: Textbook Collection at the University of Minnesota," Journal of Access Services 5, no. 1/2 (2008): 285-93.

10. Mary S. Laskowski, “The Textbook Problem: Investigating One Possible Solution," Library Collections, Acquisitions, and Technical Services 31, no. 3/4 (2007): 161-70.

11. Laura K. McElfresh, "Good Things Come in Small Libraries-College Textbooks and Libraries: If You Reserve It, They Will Come," Technicalities 29, no. 6 (2009): 4-6.

12. Molly Murphy, "Textbooks on Reserve: A Case Study," Journal of Access Services 10, no. 3 (2013): 145-52.

13. John H. Pollitz and Anne Christie, "The High Cost of Textbooks: A Convergence of Academic Libraries, Campus Bookstores, Publishers?" Electronic Journal of Academic and Special Librarianship 7, no. 2 (2006), available online at http://southernlibrarianship.icaap.org/content/ v07n02/pollitz_j01.htm [accessed 26 February 2015]; Anne Christie, John H. Pollitz, and Cheryl Middleton, "Student Strategies for Coping with Textbook Costs and the Role of Library Course Reserves," portal: Libraries and the Academy 9, no. 4 (2009): 491-510; John H. Pollitz, Anne Christie, and Cheryl Middleton, "Management of Library Course Reserves and the Textbook Affordability Crisis," Journal of Access Services 6, no. 4 (2009): 459-84. 
14. Christie et al., "Student Strategies," 491-510.

15. Pollitz et al., "Management of Library Course Reserves," 459-84.

16. Kate Pitcher, "Library Publishing of Open Textbooks: The Open SUNY Textbooks Program," Against the Grain 26, no. 5 (2014): 22-24; “Nation's Largest Free and Low-Cost Textbook Showcase Launches at 13 California State University Libraries," PR Newswire (Feb. 11, 2015).

17. Pitcher, "Library Publishing of Open Textbooks," 22.

18. "Nation's Largest Free and Low-Cost Textbook Showcase Launches," PR Newswire.

19. Charles Lyons and Dean Hendrix, "Textbook Affordability: Is There a Role for the Library?" The Serials Librarian 66, no. 1/4 (2014): 262-67; Perry, "The College Textbook Bubble."

20. Laurie Isenberg, "Online Course Reserves and Graduate Student Satisfaction," Journal of Academic Librarianship 32, no. 2 (2006): 166-72.

21. Christie et al., "Student Strategies."

22. Mara Rojeski, "User Perceptions of E-books Versus Print Books for Class Reserves in an Academic Library," Reference Services Review 40, no. 2 (2012): 228-41.

23. Katrina Schwartz, "Why College Students Still Prefer Print Over E-books," Mind/Shift (Sept. 14, 2012), available online at http://www2.kqed.org/mindshift/2012/09/14/why-college-studentsstill-prefer-print-over-e-books/ [accessed 20 February 2015].

24. Lyons and Hendrix, "Textbook Affordability," 265.

25. Elizabeth Strother et al., "Dental Students' Attitudes Towards Digital Textbooks," Journal of Dental Education 73, no. 12 (2009): 1361-65.

26. Strother et al., "Dental Students' Attitudes," 1363.

27. Strother et al., "Dental Students' Attitudes."

28. Murphy, "Textbooks on Reserve"; Pollitz and Christie, "The High Cost of Textbooks."

29. Christie, Pollitz, and Middleton, "Student Strategies"; Rojeski, "User Perceptions of Ebooks." Christie, Pollitz, and Middleton found that 93 percent of students preferred print in 2009, while, in 2012, Rojeski found that 78 percent disliked reading online.

30. Strother et. al., "Dental Students' Attitudes," 1363.

31. Crouse, "Textbooks 101"; Murphy, "Textbooks on Reserve."

32. Sheila Beck, "Queensborough Community College: Textbook Reserve Collection," Community \& Junior College Libraries 18, no. 3/4 (2012): 122.

\section{Bibliography}

Beck, Sheila. "Queensborough Community College: Textbook Reserve Collection." Community \& Junior College Libraries 18, no. 3/4 (2012): 119-26.

Christie, Anne, John H. Pollitz, and Cheryl Middleton. "Student Strategies for Coping with Textbook Costs and the Role of Library Course Reserves." portal: Libraries and the Academy 9, no. 4 (2009): 491-510.

Crouse, Caroline. "Textbooks 101: Textbook Collection at the University of Minnesota." Journal of Access Services 5, no. 1/2 (2008): 285-93.

Hsieh, Cynthia, and Rhonelle Runner. "Textbooks, Leisure Reading, and the Academic Library." Library Collections, Acquisitions, and Technical Services 29, no. 2 (2005): 192-204.

Isenberg, Laurie. "Online Course Reserves and Graduate Student Satisfaction." Journal of Academic Librarianship 32, no. 2 (2006): 166-72.

Laskowski, Mary S. "The Textbook Problem: Investigating One Possible Solution." Library Collections, Acquisitions, and Technical Services 31, no. 3/4 (2007): 161-70.

Lyons, Charles, and Dean Hendrix. "Textbook Affordability: Is There a Role for the Library?" The Serials Librarian 66, no. 1/4 (2014): 262-67.

McElfresh, Laura K. "Good Things Come in Small Libraries-College Textbooks and Libraries: If You Reserve It, They Will Come." Technicalities 29, no. 6 (2009): 4-6.

Murphy, Molly. "Textbooks on Reserve: A Case Study." Journal of Access Services 10, no. 3 (2013): 145-52.

“Nation's Largest Free and Low-Cost Textbook Showcase Launches at 13 California State University Libraries," PR Newswire. February 11, 2015. Academic OneFile [accessed 10 January 2016].

Perry, Mark J. "The College Textbook Bubble and How the 'Open Educational Resources' Movement is Going Up Against the Textbook Cartel." American Enterprise Institute. December 4, 2012. https://www.aei.org/publication/the-college-textbook-bubble-and-how-the-open-educationalresources-movement-is-going-up-against-the-textbook-cartel/ [accessed 26 June 2015].

Pitcher, Kate. "Library Publishing of Open Textbooks: The Open SUNY Textbooks Program." Against the Grain 26, no. 5 (2014): 22-24.

Pollitz, John H., and Anne Christie. "The High Cost of Textbooks: A Convergence of Academic Libraries, Campus Bookstores, Publishers?" Electronic Journal of Academic and Special Librari- 
anship 7, no. 2. (2006). http://southernlibrarianship.icaap.org/content/v07n02/pollitz _j01.htm [accessed 26 February 2015].

Pollitz, John H., Anne Christie, and Cheryl Middleton. "Management of Library Course Reserves and the Textbook Affordability Crisis." Journal of Access Services 6, no. 4 (2009): 459-84.

Rojeski, Mara. "User Perceptions of E-books Versus Print Books for Class Reserves in an Academic Library." Reference Services Review 40, no. 2 (2012): 228-41.

Sayles, Jeremy. "The Textbooks-in-College-Libraries Mystery." College \& Undergraduate Libraries 1, no. 1 (1994): 81-93.

Schwartz, Katrina. "Why College Students Still Prefer Print Over E-books." Mind/Shift. September 14, 2012. http://ww2.kqed.org/mindshift/2012/09/14/why-college-students-still-prefer-printover-e-books/ [accessed 20 February 2015].

Sommer, Robert, and Marina Estabrook. "Textbook Prices and Their Implications for Social Sciences Librarians." Behavioral \& Social Sciences Librarian 9, no. 1 (1990): 29-37.

Strother, Elizabeth A., Darlene P. Brunet, Michael L. Bates, and John R. Gallo. "Dental Students' Attitudes Towards Digital Textbooks." Journal of Dental Education 73, no. 12 (2009): 1361-65.

U.S. Government Accountability Office. College Textbooks Enhanced Offerings Appear to Drive Recent Price Increases. GAO-05-806. Washington, D.C.: U.S. Government Printing Office, 2005.

. Students Have Greater Access to Textbook Information. GAO-13-368. Washington, D.C.: U.S. Government Printing Office, 2013. 